\title{
Mycoflora and Aflatoxin levels of Left-over Harvest in some Farms, South West of Nigeria
}

\author{
Flora Oluwafemi $^{1 *}$, Aminat Omodolapo Badmos ${ }^{1}$, Adelodun Lawrence Kolapo ${ }^{2}$ \\ ${ }^{1}$ Department of Microbiology, Federal University of Agriculture, Abeokuta. Nigeria \\ ${ }^{2}$ Department of Biology, The Polytechnic, Ibadan. Nigeria.
}

\section{A R T I C L E I N F O}

\section{Article history:}

Received 30 March 2015

Accepted 09 June 2015

Available online, ISSN: 2148-127X

Keywords:

Free grazing cattle

Left-over harvest

Fungal counts

HPLC

Public health

${ }^{*}$ Corresponding Author:

E-mail: foluwafemi2000@yahoo.co.uk

\section{A B S T R A C T}

More than ninety percent of the ruminant livestock in Nigeria lies in the hands of herders who keep them under extensive and semi-intensive management systems, whereby the animals rely only on natural pasture and crop residues for survival. In this work, the mycoflora and aflatoxin levels of ten farms were determined by sampling crop residues on farms grazed by cattle. Samples of the remains of farm harvest were surfacedisinfected and cultured using standard microbiological techniques while aflatoxins in the left over harvest were determined using High Performance Liquid Chromatography (HPLC) with fluorescence detection. Fungal counts in leftover harvest ranged from $1.2 \mathrm{x}$ $10^{6}$ to $3.8 \times 10^{6} \mathrm{cfu} / \mathrm{g}$. Aspergillus flavus, A. terreus, A.parasiticus, Rhizopus sp and a yeast, Candida sp were most prevalent on all the investigated crop residues. Aflatoxin B1 (AFB1) on the crop residues ranged between 3.0 and $13.30 \mu \mathrm{g} / \mathrm{Kg}$, while the levels of AFG1 were between 2.30 and $4.50 \mu \mathrm{g} / \mathrm{Kg}$. Results of the present study is indicative that the accumulation of these doses of AFB1 can lead to transfer of AFB1 into cattle and subsequently into milk. So there is an urgent need to control the feeding pattern of cattle in order to protect the health of the consuming public.

\section{Introduction}

Aflatoxins are toxic secondary metabolites produced principally by Aspergillus species, basically A. flavus and A. parasiticus. Aflatoxins have currently become a global issue. A large fraction of the world's food, including maize, rice, sorghum, barley, rye, wheat, peanut, groundnut, soya, cottonseed and other derivative products made from these primary feedstuffs in low-income countries are contaminated with aflatoxins (Rizzi et al., 2003; Masoero et al., 2007). However, they are most prevalent in latitudes between $40^{\circ} \mathrm{N}$ and $40^{\circ} \mathrm{S}$ of the equator, but the greatest health risk lies within developing countries in tropical regions, which rely on these commodities as their staple food source (Strosnider et al., 2006). It has been estimated that more than 5 billion people in developing countries worldwide are at risk of chronic exposure to aflatoxins through contaminated foods (Shephard, 2003; Williams et al., 2004).

A 2001 study in Nigeria revealed that blood and semen aflatoxin levels ranged from 700 to 1393 and 60 to $148 \mathrm{ng} / \mathrm{ml}$ respectively in infertile men and were significantly higher than that in fertile men (Uriah et al., 2001). The high aflatoxin contents of these Nigerians' body fluids might not be unconnected with their dietary exposure. Nigerian basic staple foods such as garri, beans, yam flour, melon, rice and maize contain high levels of aflatoxins (Ibeh et al., 1991; Jimoh and Kolapo, 2008; Somorin et al., 2012) and it is a common practice for these staples to be eaten with animal protein accompaniments.

Maina (1986) stated that meat constitutes the foremost animal product that is highly explored by the Nigerian households particularly for direct consumption and as such, the ruminants especially cattle, constitutes the major and cheapest source of meat consumption for most households in Nigeria. However, over 90 percent of the ruminant livestock in Nigeria lies in the hands of herders who keep them under extensive and semi-intensive management systems, whereby the animals only rely on natural pasture and crop residues for survival (LawalAdebowale, 2012). On the understanding that hay, which contains a large complement of cereal grain infested in the field, could be a source of appreciable aflatoxins (Lizarraga-Paulin et al., 2012), it is possible that animal products, in addition to staple foods might be contributing an appreciable quantum to dietary aflatoxin exposure in Nigeria. Due to the presence of aflatoxin M1 in cows' milk ranging from $9-456 \mathrm{ng} / \mathrm{L}$ (Oluwafemi et al., 2014), this present study was conducted to determine if crop residues could be source of exposure to aflatoxins by evaluating animal feed intake in the grazing areas. 


\section{Materials and Methods}

Study Areas

Ibadan and Abeokuta are two important cities in south west Nigeria located in Oyo and Ogun states respectively. They are located in the tropical Rain Forest zone with high humidity and temperature. Cultivation of crops in these suburbs is transforming the vegetation into a wooded savanna, which incidentally favours the herding of cattle by the Fulani Pastorialists in communities within the study areas which feed the cattle forage and left-over harvest of cultivated crops such as maize.

\section{Collection of left over harvest sample}

Left over harvest of maize cobs, maize grains, cassava roots, cassava stem, sugar cane, cocoyam, pepper were randomly collected from farms in Abeokuta and Ibadan grazed by cattle of the Fulani herdsmen. The left over harvest were collected into a sterilized polyethylene bag and were taken to the laboratory for analysis.

Coordinates of the collecting points were obtained using a hand-held Global Positioning System (GPS), and the areas are shown in figure 1.

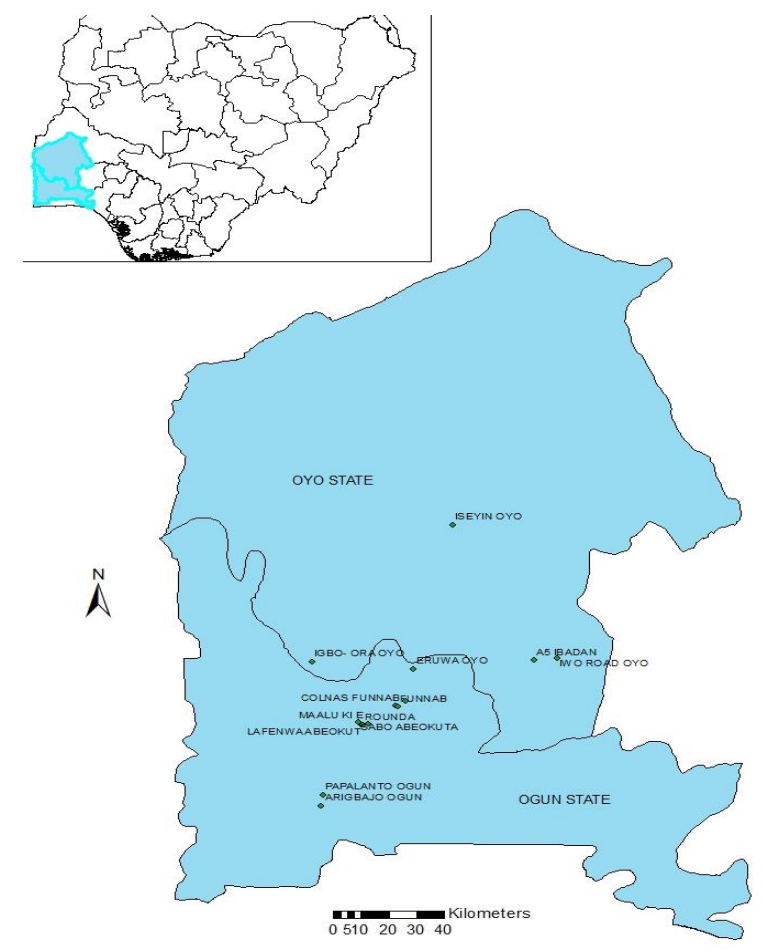

Figure 1 Location of sample collection points.

\section{Isolation and characterization of fungi in left over harvest}

Fungi were isolated from the collected left over harvest according to the method described by Klich (2002). The left over harvest were surface disinfected with ethanol. Serial dilution of the samples was done and appropriate dilutions were plated on Sabouraud dextrose agar at $28^{\circ} \mathrm{C}$ for five days and the fungal counts estimated in $\mathrm{cfu} / \mathrm{g}$. Aspergillus isolates were identified using morphological and cultural characteristics as highlighted by Klich (2002).

\section{Chemicals}

Standards of aflatoxin B1, B2, G1, and G2 were supplied by Supelco, Bellefonte, Pennsylvania, USA. Solvents such as acetonitrile, methylene chloride, and methanol were of High Performance Liquid Chromatography(HPLC) grade.

Aflatoxin quantification of left over harvest: The method adopted by Oluwafemi et al., (2010) was used, where $50 \mathrm{~g}$ of each sample was milled with $70 \%$ methanol and filtered with Whatman No.1 filter paper. The dried extract was re-dissolved with $1.25-\mathrm{ml}$ of acetonitrile: water $(25: 75, \mathrm{v} / \mathrm{v}$ and was subjected to HPLC.

Table 3 shows the morphological and cultural characteristics of fungal isolates. Isolates were characterized according to the schemes of Klich (2002) and they were A. parasiticus, A. flavus, Candida sp. A. terreus, and A. niger. Figures 2-4 show chromatograms of both standard and left over harvest AFB1, AFB2, AFG1 and AFG2. Table 4 shows aflatoxin level in left over harvest from the randomly selected farms. AFB1 ranged between 3.3 .0 and $13.30 \mu \mathrm{g} / \mathrm{Kg}$, while the levels of AFG1 were between 2.30 and $4.50 \mu \mathrm{g} / \mathrm{Kg}$.

\section{Results}

The geographical region covered by this study showing the coordinates is clearly shown in figure 1 and Table 1. The mean fungal counts and the mycoflora profile of the left over harvest in the randomly selected farms grazed by Fulani Pastorialist in Abeokuta and Ibadan suburbs are presented in Table 1. Results obtained depicted that the fungal counts ranged from $1.20 \times 10^{6}$ to $3.80 \times 10^{6} \mathrm{cfu} / \mathrm{g}$. Moulds such as Aspergillus flavus, A. terreus, A.parasiticus, Rhizopus sp and a yeast, Candida $\mathrm{sp}$ were the most prevalent on all the investigated crop residues. Aflatoxin B1 (AFB1) on the crop residues ranged between 3.0 and $13.30 \mu \mathrm{g} / \mathrm{Kg}$, while the levels of AFG1 were between 2.30 and $4.50 \mu \mathrm{g} / \mathrm{Kg}$.

Table 1 Latitude and Longitude of Left-over Harvest Sample Collection Points

\begin{tabular}{l|cc}
\hline \multicolumn{1}{c}{ Location } & Latitude & Longitude \\
\hline Eruwa Oyo (A) & 7.374997 & 3.496857 \\
Igbo Ora Oyo (B) & 7.403869 & 3.164978 \\
Iseyin Oyo (C) & 7.941188 & 3.623200 \\
Adamasingba Oyo(D) & 7.409861 & 3.888588 \\
A5-Ibadan Oyo (E) & 7.395425 & 3.791685 \\
Papalanto Ogun (F) & 6.882528 & 3.202972 \\
Arigbajo Abeokuta (G) & 6.839033 & 3.196564 \\
Lafenwa Ogun (H) & 7.157254 & 3.325981 \\
Sabo Ogun (I) & 7.168428 & 3.316295 \\
Funaab Ogun(J) & 7.227203 & 3.472481 \\
\hline
\end{tabular}

\section{Discussion}

Mycoflora profile of left-over harvest in farms sampled compares favourably with the reports of Gbodi et al. (1986) who isolated A. parasiticus, A. flavus, Candida sp, A. terreus and A. niger. Bankole et al. (2006) and Jimoh and Kolapo (2008) on their separate studies of "Egusi" melon seeds and cereal grains reported these 
fungi were found associated with cereal grains due to the humid tropical climate. The presence of fungi in crops in large numbers does not automatically mean aflatoxin contamination (Olojede et al., 1996, but the analysis for the different aflatoxin showed that maximum aflatoxin levels in left-over harvest in this study was $13.3 \mu \mathrm{g} / \mathrm{kg}$ while the lowest level of aflatoxin was $3.3 \mu \mathrm{g} / \mathrm{kg}$.
In a documentatary by Cornell University (2009), it listed that the maximum permissible worldwide aflatoxin levels in feeds for dairy and finishing beef cattle were 20 and $300 \mu \mathrm{g} / \mathrm{Kg}$ respectively. The concentration levels of aflatoxin levels from this study were lower but consulting earlier studies by Oluwafemi et al (2014) which obtained values between $9.0-456 \mathrm{ng} / \mathrm{L}$ in some grazing areas give an indication that there are some levels of carry-over.

Table 2 Mycoflora and ${ }^{\dagger}$ Fungal counts (cfu/g) of Left-over Maize Harvest on farms grazed by Cattle in Ibadan/Abeokuta Suburbs, South West Nigeria

\begin{tabular}{|c|c|c|}
\hline Farm & Fungal Counts & Fungal Isolates \\
\hline $\bar{A}$ & $1.20 \times 10^{6}$ & Aspergillus flavus, A. niger, A. parasiticus, Rhizopus $\mathrm{sp}$ \\
\hline B & $1.76 \times 10^{6}$ & A. flavus, A. niger, A. parasiticus \\
\hline $\mathrm{C}$ & $1.80 \times 10^{6}$ & A.terreus, A. flavus, Candida $\mathrm{sp}$, Rhizopus $\mathrm{sp}$ \\
\hline $\mathrm{D}$ & $3.80 \times 10^{6}$ & A.terreus, A. flavus, Candida sp, Rhizopus $\mathrm{sp}$ A. parasiticus \\
\hline $\mathrm{E}$ & $1.83 \times 10^{6}$ & A. flavus, Candida sp, Rhizopus sp A. parasiticus \\
\hline $\mathrm{F}$ & $2.20 \times 10^{6}$ & A. parasiticus, A. niger, A. flavus, Rhizopus sp \\
\hline G & $5.00 \times 10^{6}$ & A. flavus, A. terreus, Rhizopus, Candida sp \\
\hline $\mathrm{H}$ & $3.00 \times 10^{6}$ & A. flavus, A. terreus, Candida sp, Rhizopus sp \\
\hline I & $3.40 \times 10^{6}$ & A. flavus, A. parasiticus, Candida $\mathrm{sp}$, A. terreus \\
\hline $\mathrm{J}$ & $1.80 \times 10^{6}$ & A. niger, A. parasiticus, A. flavus, Candida sp \\
\hline
\end{tabular}

Table 3 Cultural and morphological characteristics of organism found in raw milk

\begin{tabular}{|c|c|c|c|}
\hline \multirow{2}{*}{ Isolates } & \multicolumn{2}{|l|}{ Features } & \multirow{2}{*}{ Probable spp } \\
\hline & Microscopic & Macroscopic & \\
\hline $\mathrm{F} 1$ & $\begin{array}{l}\text { Spores are oval, non septate brown } \\
\text { mycelium gives rise to straight sporan- } \\
\text { giosphore that terminate with black spo- } \\
\text { rangium containing a columella, with a root- } \\
\text { like hyphae (rhizoids). }\end{array}$ & $\begin{array}{l}\text { Rapidly growing white coloured } \\
\text { fungus swarms over entire plate, } \\
\text { aerial mycelium cottony and } \\
\text { fuzzy. }\end{array}$ & Rhizopus \\
\hline $\mathrm{F} 2$ & $\begin{array}{l}\text { Conidia heads are typically radiate, later } \\
\text { splitting to form loose column } \\
\text { conidiophores arehyaline and coarsely } \\
\text { roughened, often more noticed near the } \\
\text { vesicles. }\end{array}$ & $\begin{array}{l}\text { White colonies becomes } \\
\text { yellowish green, grows in a cycle } \\
\text { manner. }\end{array}$ & A. flavus \\
\hline $\mathrm{F} 3$ & $\begin{array}{l}\text { Vesicles are small, dome shaped biseriate, } \\
\text { proximal phialides are shorter than distal } \\
\text { philiades,smooth, elliptical conidia form } \\
\text { long chains, has microconidia borne by } \\
\text { short conidiophores which extend laterally } \\
\text { from hyphae. }\end{array}$ & $\begin{array}{l}\text { Colonies are velvety, brown with } \\
\text { folds, the reverse is white }\end{array}$ & A. terreus \\
\hline F4 & $\begin{array}{l}\text { spores are oval, non-septate mycelium give } \\
\text { straight spores. }\end{array}$ & $\begin{array}{l}\text { Colonies are greenish- yellow } \\
\text { and grows in a trio shape. }\end{array}$ & A. parasiticus \\
\hline F5 & spores are oval, non-septate & $\begin{array}{l}\text { Colonies are creamy grows by } \\
\text { budding }\end{array}$ & Candida sp \\
\hline
\end{tabular}

Table 4 Aflatoxins $B_{1}$ and $G_{1}$ levels of left over harvest in ten farms

\begin{tabular}{c|cc}
\hline Farm $\mathrm{G} 1(\mu \mathrm{g} / \mathrm{Kg})$ & Aflatoxin B1 $(\mu \mathrm{g} / \mathrm{Kg})$ & Aflatoxin \\
\hline 1 & 12.0 & 4.5 \\
2 & 13.3 & 2.7 \\
3 & 3.3 & 2.3 \\
4 & 7.4 & 3.6 \\
5 & 5.9 & 2.4 \\
6 & 3.3 & 4.1 \\
7 & 7.0 & 4.0 \\
8 & 4.6 & 3.2 \\
9 & 5.5 & 3.0 \\
\hline
\end{tabular}


Britzi et al. (2013), in their study for low yielding cows reported a value of $1-2 \%$. This observation has an implication for this study as it perfectly agrees with both AFB1 values and the carry-over into milk as reported earlier by Oluwafemi et al., (2014). Nigerian cows according to Shittu et al. (2008) are low yielding producing about $24 \mathrm{~L}$ of milk per day. In the study by Britzi et al. (2013), the maximum aflatoxin $\mathrm{B}_{1}$ levels in feed should not exceed $1.4 \mu \mathrm{g} / \mathrm{Kg}$. Values of AFB1 in all ten farms surveyed exceeded this amount. It has been reported that $40 \mu \mathrm{g} / \mathrm{Kg} \mathrm{AFB} 1$ reduces productivity in some animal species (Denli and Okan, 2006).

Apart from the initial concentration of AFB1, other factors that affect carryover rate, include species difference, overall health of the cattle, hepatic biotransformation capacity, rate of ingestion and integrity of mammalian alveolar membranes (Battacone et al., 2003; Fink-Gremmels, 2008).

It is widely acknowledged that in tropical countries, giving an aflatoxin-free feed to animals is practically impossible, therefore the needed efforts to stem the tides of aflatoxicosis in these countries as documented by Jones et al. (1994) and Vincelli et al. (2002), include: gestating, lactating and stressed cattle should not be fed with feeds containing more than $20 \mu \mathrm{g} / \mathrm{Kg}$; unstressed growing finishing cattle in excess of 400 pounds may be fed diets containing up to $100 \mu \mathrm{g} / \mathrm{Kg}$ of aflatoxins and animals destined for slaughter should receive aflatoxin free diets for at least 3 weeks before slaughter.

As reported earlier, over $90 \%$ of the ruminant livestock in Nigeria are kept under extensive and semiintensive management system (Lawal-Adebowale, 2012), results of the present study had shown the need to domesticate the provisions of Jones et al. (1994) and Vincelli et al. (2002) in Nigeria and similar countries if the health of the consuming public must be protected.

\section{References}

Bankole SA, Ogunsanwo BM, Osho A, Adewuyi GO. 2006. Fungal contamination and aflatoxin B1 of 'egusi' melon seeds in Nigeria. Food Control 17: 814-818.

Battacone G, Nudda A, Cannas A, Borlino AC, Bomboi G, Paulina G. 2003. Excretion of aflatoxin M1 in milk of dairy ewes treated with different doses of aflatoxin B1. J Dairy Sci 86: $2667-2675$.

Britzi M, Friedman S, Miron J, Solomon R, Cuneah O, Shimshoni JA, Soback S, Ashkenazi R, Armer S, Sholberg A. 2013. Carry-over of Aflatoxin $B_{1}$ to Aflatoxin M1 in High Yielding Israeli Cows in Mid- and late-lactation. Toxins 5: 173-183.

Cornell University. 2009. Aflatoxins: Occurrence and Health Risks. In: Plant Poisonous in Livestock. Cornell University, Department of Animal Science. http://www.ansci.cornell.edu/ plants/ toxicagents/ aflatoxin/ aflatoxin.htm

Denli M, Okan F. 2006. Effect of different adsorbents in reducing the toxic effects of aflatoxin B1 in broiler diets South African. J Animal Sci 36: 97-103.

Fink-Gremmels J. 2008. Mycotoxins in cattle feeds and carryover to dairy milk: A review. Food Addit Contam. 25: 172-180.

Gbo Gbodi TA, Nwude N, Aliu YO, Ikediobi CO. 1986. The mycoflora and some mycotoxins found in maize (Zea mays) in the Plateau state of Nigeria. Vet Human Toxicol 28: 1-5.
Ibeh IN, Uriah N, Ogonor UI. 1991. Dietary exposure to aflatoxin in Benin City, Nigeria: a possible public health concern. Int J Food Microbiol 14: 171-174.

Jimoh KO, Kolapo AL. 2008. Mycoflora and Aflatoxin production in Market Samples of Some Selected Nigerian Foodstuffs. Res J Microbiol 3: 169-179.

Jones FT, Beth M, Genter MM, Hagler WM, Hansen JA, Mowrewy BA, Poore MH, Whitlow LW. 1994. Understanding and coping with effects of mycotoxins in livestock feed and forage. Electronic publication No. DRO- 29, NCCES, North Carolina State Univ., Raleigh, North Carolina.

Klich MA. 2002. Identification of common Aspergillus species Centraalbureau voor schimmel cultures Netherlands pp. 1-116.

Lawal-Adebowale OA. 2012. Dynamics of ruminant livestock management in the context of the Nigerian Agricultural system. In: Livestock Production. Pp 61-80. http://dx.doi.org/10.5772/ 52923.

Maina JA. 1986. Animal health in sub-humid Nigeria. In: Proceedings of ILCA/NAPRI Symposium, Kaduna, Nigeria 29 October- 2 November, 1984. ILCA, Addis-Ababa.

Masoero F, Gallo A, Moschini M, Piva G, Díaz D. 2007. Carryover of aflatoxin from feed mycotoxins found in maize (Zea mays) in the Plateau state of Nigeria. Animal, 1: 1344-1350.

Olojede F, Engelhardt C, Wallnofer PR, Adegoke GO. 1993. Decrease of growth and aflatoxin production in Aspergillus parasiticus infected maize grains caused by spices. World $\mathbf{J}$ Microbiol Biotechnol 9:600-606

Oluwafemi F, Bandyopadhyay R, Manjula K, Ogunbanwo T, Ayanwande BK. 2010. Bio- detoxification of aflatoxin b1 in artificially-contaminated maize grains using lactic acid bacteria. Toxin Rev 29: 115-122.

Oluwafemi F, Badmos AO, Kareem SO, Ademuyiwa O. Kolapo AL 2014. Survey of Aflatoxin M1 in milk of free grazing cows. Mycotoxin Res 30: 207- 211.

Rizzi L, Simoli M, Roncada P, Zaghini A. 2003. Aflatoxin $B_{1}$ and clinoptiloite in feed for laying hens: effects on egg quality, mycotoxin residues in livers and hepatic mixed function oxygenases activities. J Food Prot 66: $860-865$.

Shephard GS. 2003. Aflatoxin and food safety: recent African perspectives. J Toxicol 22:267-286.

Shittu A, Junaidu AU, Chafe UM, Magaji AA, Faleke OO, Salihu MD, Jibril A, Mahmud MA. A survey on current milk production and pricing in Sokoto State, Nigeria. Sokoto J Vet Sci 7:53-58

Somorin YM, Bertuzzi T, Battilani P, Pietri A. 2012. Aflatoxin and fumonisin contamination of yam flour from markets in Nigeria. Food Cont 25:53-58.

Strosnider H, Azziz-Baumgartner E, Banziger M, Bhat RV, Breiman R, Brune MN, DeCock K, Dilley A, Groopman J, Hell K, Henry SH, Jeffers D, Jolly C, Jolly P, Kibata GN, Lewis L, Liu X, Luber G, McCoy L, Mensah P, Miraglia M, Misore A, Njapau H, Ong CN, Onsongo MT, Page SW, Park D, Patel M, Phillips T, Pineiro M, Pronczuk J, Rogers HS, Rubin C, Sabino M, Schaafsma A, Shephard G, Stroka J, Wild C, Williams JT, Wilson D. 2006. PublicHealth Strategies for Reducing Aflatoxin Exposure in Developing Countries: A Workgroup Report. Environ Health Perspect 12:1898-1903.

Uriah N, Ibeh IN, Oluwafemi F. 2001. A Study on the Impact of Aflatoxin on Human Reproduction. Afr J Reprod Health 5:106110.

Vincelli P, Paker G, McNeill S. 2002. "Aflatoxin in corn." Kentucy Pest News 1353: 1-17. http://www2.ca.uky.edu/agc/pubs/id/ id59/ id59.pdf (Accessed: 10.08.2015)

Williams JH, Philips TD, Jolly PE, Stiles JK., Jolly CM, Aggarwal D. 2004. Human aflatoxicosis in developing countries: A review of toxicology, exposure, potential health consequences and interventions. Am J Clinical Nut 80:1106-1122. 